\title{
ON THE VIEW OF KALMYK KHAN TO THE ACTIVITES OF RUSSIA IN THE VOLGA-CASPIAN FRONTIER: FROM THE LETTERS OF DONDUK-DASHI TO V. TATISHCHEV, 1741-1745 ${ }^{1}$
}

\author{
Zhanat B. Kundakbayeva \\ Al-Farabi Kazakh National University, Almaty, Kazakhstan
}

\section{Danara A. Suseeva}

B.B. Gorodovikov Kalmyk State University, Elista, Russian Federation

\begin{abstract}
Introduction. The article based on Michael Adas's analytical category "avoidance protest" presented by Paul W. Werth examines the view of the Kalmyk khan on the activities of the Russians to strengthen positions on the Volga-Caspian frontier, when V. Tatishchev was the head of the Kalmyk Commission and Astrakhan Governor, between 1741 and 1745. Methods and materials. Whereas previous studies considered only the Russian view on the politics toward the region and determined the attitudes of nomadic elites in terms of absolute compliance or violent opposition. However, in practice the relations between Russian authorities and indigenous people's elite were much more complex.Using as primary sources the letters of Donduk-Dashi to V. Tatishchev of the period between 1741 and 1745 from the National Archive of the Kalmyk Republic published by prof. D. Suseeva gives us an opportunity to examine the situation from below. Analysis and Results. We argue that although Donduk-Dashi was quite embedded within the Russian system, we cannot claim about his unconditional subordination. First, speculating on general Tarakanov's misstep, Donduk-Dashi evaded investigations regarding the plans to relocate to the protectionof Persian shah. The second argument was built around his alleged unawareness about theposition of Russian authorities regarding the Kazakh-Kalmyk relations and entreaties to provide with guns as an attempt to divert attention away from current problems on the relations with the Kazakhs. The formal notification of the forthcoming marriage of the Kalmyk nobleman with Kazakh princess and about non-sanctioned contacts with Kazakh Middle zhuz khan demonstrates that nomad's relations i went beyond the line prescribed by the government. guns, marriage of the Kalmyk nobleman with Kazakh princess, Kazakh Middle zhuz khan.

Citation. Kundakbayeva Zh.B., Suseeva D.A. On the View of Kalmyk Khan to the Activites of Russia in the Volga-Caspian Frontier: From the Letters of Donduk-Dashi to V. Tatishchev, 1741-1745. Vestnik Volgogradskogo gosudarstvennogo universiteta. Seriya 4. Istoriya. Regionovedenie. Mezhdunarodnye otnosheniya [Science Journal of Volgograd State University. History. Area Studies. International Relations], 2020, vol. 25, no. 5, pp. 32-41. (in Russian). DOI: https://doi.org/10.15688/jvolsu4.2020.5.3
\end{abstract}




\title{
ВЗГЛЯД КАЛМЫЦКОГО НАМЕСТНИКА НА ПОЛИТИКУ РОССИИ ПО УКРЕПЛЕНИЮ ВОЛГО-КАСПИЙСКОГО ФРОНТИРА: ИЗ ПИСЕМ ДОНДУК-ДАШИ В.Н. ТАТИЩЕВУ, 1741-1745 гГ. ${ }^{1}$
}

\author{
Жанат Бековна Кундакбаева \\ Казахский национальный университет им. аль-Фараби, г. Алматы, Республика Казахстан
}

\section{Данара Аксеновна Сусеева}

Калмыцкий государственный университет им. Б.Б. Городовикова, г. Элиста, Российская Федерация

Аннотация. Введение. В статье на основе аналитической категории Майкла Эйдаса «протест путем уклонения» представляется взгляд калмыцкого правителя на мероприятия российского правительства по укреплению позиций в Волго-Каспийском фронтире, когда на В.Н. Татищева было возложено руководство Калмыцкой комиссией и должность астраханского губернатора (1741-1745 гг.). Mетоды и материаль. В предыдущих исследованиях в основном представлялся российский взгляд. А при изучении отношения кочевой элиты к российскому присутствию рассматривались либо как полное подчинение, либо как отчаянное сопротивление. Между тем на практике данные взаимоотношения не были столь однозначными. В качестве источниковой базы использованы письма наместника Калмыцкого ханства Дондук-Даши к В.Н. Татищеву периода Калмыцкой комиссии на калмыцком языке и русских переводах XVIII в. из фондов Национального архива Республики Калмыкия, опубликованных Д. Сусеевой. Анализ и результаты. В статье был сделан вывод о том, что хотя Дондук-Даши как ставленник российского правительства был вполне вписан в российскую систему, нельзя говорить об его безоговорочном подчинении. Об этом свидетельствуют следующие факты: спекулируя на оплошности генерал-лейтенанта Тараканова, смог уклониться от расследований относительно планов перейти вместе с калмыками в подданство персидского шаха. Другим аргументом является его якобы неведение о планах России относительно калмыцко-казахских отношений и настойчивые просьбы снабдить пушками, как попытка отвести внимание от взаимных набегов с казахами. И наконец, его уведомление о предстоящем браке между калмыцким владельцем и казахской принцессой, а также о пересылке и приеме послов от хана Среднего жуза говорит о том, что в своих контактах кочевники выходили за рамки, предписанные правительством. Использование документов, исходивших от подчиненных народов, позволяет создать более панорамную картину взаимоотношений. Д. Сусеева выявила и перевела на русский язык письма Дондук-Даши к В.Н. Татищеву. Ж. Кундакбаева сделала их исторический анализ.

Ключевые слова: письма Дондук-Даши к В.Н. Татищеву, Волго-Каспийский фронтир, «оплошность» генерала Тараканова, пушки, брак между детьми казахских и калмыцких владетелей, хан Среднего жуза.

Цитирование. Кундакбаева Ж. Б., Сусеева Д. А. Взгляд калмыцкого наместника на политику России по укреплению Волго-Каспийского фронтира: из писем Дондук-Даши В.Н. Татищеву, 1741-1745 гг. // Вестник Волгоградского государственного университета. Серия 4, История. Регионоведение. Международные отношения. -2020. - Т. 25, № 5. - C. 32-41. - DOI: https://doi.org/10.15688/jvolsu4.2020.5.3

Введение. Внутриполитическое положение Калмыцкого ханства и как Российской империи удалось погасить конфликт после смерти Дондук-Омбов 1741 г. обстоятельно изучено многими поколениями историков [1; 24]. В историографии достаточно внимания уделено и многогранной деятельности В.Н. Татищева в качестве руководителя Калмыцкой комиссии и астраханского губернатора (1741-1745 гг.). В этот период на него были возложены сложные задачи по расширению российского присутствия на Нижней Волге. Данный вопрос обстоятельно изучен в монографии Н. Попова [11]. Много подробностей об этом этапе жизни В.Н. Татищева содержится в работах Н. Пальмова [6-8]. В современный период данному вопросу уделяют внимание И. Торопицын [18-21], Ж. Кундакбаева $[4 ; 5]$ и Д. Сусеева [16; 17]. Так, в монографии Ж. Кундакбаевой на основе многочисленных архивных документов был представлен системный взгляд на мероприятия Российс- 
кой империи по регулированию отношений между калмыками и казахами в 1740-е годы [5]. Особую ценность имеют публикации Д. Сусеевой и А. Хараевой, в которых дается квалифицированный лингвистический анализ калмыцким документам, хранящимся в Национальном архиве Республики Калмыкия (далее - НАРК) [17; 23]. Несмотря на то что в научный оборот введены сотни новых документов, а разные стороны деятельности В.Н. Татищева в качестве руководителя Калмыцкой комиссии стали предметом исследования отдельных статей, все еще есть малоизученные аспекты в данной теме. К ним относится дефицит исторических исследований, написанных на основе документов, исходивших непосредственно от калмыков. Поэтому в данной статье, используя благоприятную возможность - наличие писем Дондук-Даши В.Н. Татищеву в 1741-1745 гг., представлена калмыцкая точка зрения на мероприятия правительства по усилению своего присутствия в Волго-Каспийском фронтире Российской империи. Цель данной статьи - показать те неявные формы сопротивления, которые демонстрируют кочевники в ответ на попытки правительства усилить единство между регионом и центром, то есть интегрировать фронтирную зону в состав Российской империи.

Методы и материалы. Теоретической основой статьи является аналитическая категория «протест путем уклонения». Ее предложил использовать американский историк Пол Верт. В своих новейших исследованиях он призывает отойти от однозначных оценок поведения подвластных народов в ответ на политику России - только лишь безоговорочного подчинения или сопротивления в виде бунтов, откочевок и восстаний. Для изучения менее конфронтационных, «повседневных форм сопротивления〉 он предлагает использовать аналитический потенциал категории «протест путем уклонения», введенной Майклом Эйдасом. «“Протест путем уклонения" - способ, при помощи которого недовольные группы людей пытаются облегчить тяготы своей жизни и выразить недовольство посредством кратковременного отказа исполнять предписанное, а также других действий, сводящих к минимуму возможность столкновения с теми, кого они считали своими притеснителями» [2, с. 35$]$.
Национальный архив Республики Калмыкия содержит богатейший материал по русско-казахским и русско-калмыцким взаимоотношениям в XVIII веке. В частности, в папках хранится более сорока дел. Каждое дело содержит от двухсот до тысячи шестисот листов документов Калмыцкой комиссии 1741-1745 гг., когда главой был В.Н. Татищев. В этом смысле исследовательские возможности материалов Калмыцкой комиссии неисчерпаемы. В данной статье нас интересует дело № 163 «Письма ДондукДаши. Донесения, рапорты и письма на калмыцком языке», которые ввела в научный оборот Д. Сусеева в 2009 году [17].

Анали 3. В письмах Дондук-Даши В.Н. Татищеву 1741-1745 гг. можно увидеть его отношение к тем или иным мероприятиям правительства в регионе. Так, например, представляет интерес письмо Дондук-Даши В.Н. Татищеву от 3 января 1743 года. В нем калмыцкий наместник отказывается отдать письмо генерал-лейтенанта А. Тараканова: «Тараканова письма без калежского указа отдать мне невозможно» [9, л. 14-14 об.]. Что это было за письмо? И почему мы придаем такое значение этому сообщению?

Сначала обратимся к деятельности Калмыцкой комиссии в 1741 году. Как известно, во время калмыцкого междоусобия специальной грамотой от 13 августа 1741 г. был направлен из Петербурга в Астрахань для успокоения калмыцкого народа тайный советник В.Н. Татищев в качестве главы Калмыцкой комиссии [5, с. 219]. До его прибытия задачи охранения калмыков от нападений казахов координировались Коллегией иностранных дел, которая стягивала военные силы с различных сторон на Царицынскую линию в распоряжение полковника П.Ф. Кольцова (царицынского коменданта) и В.П. Беклемишева (состоящего при калмыцких делах). 22 сентября 1741 г. были отправлены указы об охранении калмыцких улусов от киргиз-кайсацких набегов генерал-майору Л.Я. Соймонову, которому было рекомендовано поступать по тамошним обстоятельствам по «усмотрению» и иметь сношение с В.Н. Татищевым. Одновременно такой же указ был отправлен и к генерал-лейтенанту А. Тараканову в Царицын. Коллегия иностранных дел указала А. Тараканову, «дабы 
калмыцкие улусы при нынешних худых состояниях от киргиз-кайсаков были охранены и для того, которые из них (калмыков. - Ж. К., Д. С.) будут находиться близ Царицына, переправить в линию, а других - на нагорную сторону, которые куда будут способнее. Рекомендовано поступать согласованно с тайным советником В.Н. Татищевым. И всем вам надлежит поступать по тамошним обстоятельствам, ибо отсюда всего того определения описать невозможно» [5, с. 219]. В указах А. Тараканову особо подчеркивалась необходимость совместных действий с В.Н. Татищевым. После прибытия В.Н. Татищева Коллегия предписывала А. Тараканову разработать совместный план мероприятий - каким образом «будущею зимою калмыцкие улусы от киргизкайсацких нападений удобнее охранять» [22].

До своего прибытия в Астрахань В.Н. Татищев попросил А. Тараканова и полковника П.Ф. Кольцова разработать предварительный план «для выполнения возложенной на В.Н. Татищева Калмыцкой комиссии». Но, как показали последующие события, из них не получилась слаженная команда. Осенью 1741 г. В.Н. Татищев запросил у А. Тараканова помощь: «две роты драгун для переходу с ним на луговую сторону, да два драгунских полка по требованию В.Н. Татищева должны были быть в готовности, выступить по его первому зову». Но А. Тараканов «в войсках отказал, из Астрахани и форпостов войск не собрал и время упустил» [13, л. 7-9]. В рапорте от 25 ноября 1741 г. А. Тараканов оправдывался перед Коллегией, почему не дал требуемых войск - «опасался с подданными Вашего Императорского Величества без высочайшего указа в бой вступать» [14, л. 14-14 об., 15].

Следующий момент разногласий в действиях уже появился зимой 1741 года. Без ведома В.Н. Татищева А. Тараканов просил Коллегию иностранных дел разрешить «отпустить драгунскую команду, поставленную в Черном Яру для охранения от киргиз-кайсаков, на квартеры». Он написал о причинах, почему нужно было распустить войска: во-первых, в Черном Яру, куда к имеющимся там четыремстам солдатам В.Н. Татищев перевел пятьсот драгун с Дона, не имелось в достаточном количестве овса и сена, вследствие чего у лошадей начался голод. Во-вторых, он отметил, что калмыки ушли в Мочаги, за Астрахань: за дальностью расстояния их с Дону и Черного Яру «от киргиз-кайсак оборонять никак невозможно», а надлежит охранять из Астрахани, поскольку, когда калмыки бывали в Мочагах (Мочаги - топкие, низменные прибрежья Каспийского моря. - Ж. К., Д. С.) за Астраханью, казахи, направляясь на них, переходили Волгу ниже Астрахани [15, л. 19-19 об.].

Впрочем, не дождавшись указа от Коллегии, 20 декабря 1741 г. А. Тараканов вскоре уже донес, что без позволения отпустил солдат и драгун с форпостов: «от настоящей здесь жестокой стужи многие драгуны и солдаты руки и ноги ознобили и к службе негодны, того ради без письма В.Н. Татищева принужден я драгун и солдат отпустить в Царицын, в квартеры» [15, л. 20 об.].

Указанное в начале статьи письмо Дондук-Даши имеет отношение уже к третьему разногласию между А. Таракановым и В.Н. Татищевым. Оно носило международный характер. Дело в том, что А. Тараканов дал знать Дондук-Даше о подозрениях и расследованиях Коллегии иностранных дел о его намерении уйти с другими калмыцкими владельцами к персидскому шаху и тем самым нарушил планы центрального правительства. Предысторию этого вопроса осветил И.В. Торопицын. Так, он отметил, что в конце октября 1742 г. командующий войсками на Царицынской линии бригадир Фролов-Бегреев узнал от своих информаторов о намерениях персидского шаха принять в подданство всех калмыков. Информатор утверждал, что через одного из жителей Кизляра персидский шах уговорил всех калмыцких старшин, в том числе и самого Дондук-Даши, перейти под его покровительство.

В.Н. Татищев воспринял данную информацию относительно ханши Джан, и не имел подозрений относительно Дондук-Даши. Тем не менее он дал задание своим информаторам в калмыцких улусах следить за фактами переписки наместника Дондук-Даши и других зайсангов с зарубежными правителями. Вот об этой слежке и узнал Дондук-Даши. То есть ему стало известно, что российское правительство подозревает его в связях с персидским шахом. И.В. Торопицын также считает, что виновником утечки информации был генерал- 
лейтенант А. Тараканов, начальник Персидской экспедиции. Его вина заключалась в том, что он показал письмо из Коллегии о необходимости установки слежки за калмыцкими владельцами насчет контактов с персидским шахом, не прикрыв при этом имя калмыцкого наместника. И.В. Торопицын отмечает, что В.Н. Татищев старался погасить конфликт, оправдывался перед наместником тем, что переводчики А. Тараканова ошиблись и неправильно передали содержание письма, он говорил ему, что никто его не подозревает, а речь идет о Джан и ее сторонниках. Несмотря на заверения В.Н. Татищева, «наместник при этом весьма невесел остался» [21, с. 55].

В нашем распоряжении имеются документы из Архива внешней политики Российской империи. Из них понятно, что В.Н. Татищев известил Коллегию об инциденте, которая, рассмотрев данный вопрос, вынесла решение: «наместнику ханства Дондук-Даше в том нималого сумнения и огорчения не наводить и для того пристойным образом спросить у него письмо генерала Тараканова и оное прислать сюда. А его наместника в том прилежно увещевать, от сумнения всячески отвадить и если сами от сумнения отвести не могут отдать приложенное письмо от вицеканцлера». В приложенном к решению Коллегии «для увещевания» письме от вице-канцлера Дондук-Даше, во-первых, говорится, что они послали ему для знакомства письмо ханши Джан персидскому шаху, которому она ранее в Кабарде «присягу учинила, и на таких условиях, чтобы он вас низложил, а сына ее на калмыцкое ханство возвесть». Во-вторых, всячески стараются уверить наместника в том, что ни малейшим образом его ни в чем не подозревают: «Его Императорскому Величеству верной службе известно» $[3$, л. $1-$ 2]». В перехваченном письме, помимо всего прочего, содержится просьба: «Прошу прадеда моего Аюки-хана с отцом моим владелые калмыцкие улусы от россиян отобрать и мне поручить и дозволить нам иметь наш закон» [3, л. 3-4].

Письмо Дондук-Даши В.Н. Татищеву от 3 января 1743 г. из Буркна весьма информативно [10, л. 14-14 об., 15]. Дондук-Даши уклонялся от приказа Коллегии отдать письмо Тараканова. При уклонении он использовал различные приемы: нашел предлог, ставил условие и делал вид, что оскорблен. На это указывают лексические приемы в письме. Так, для Дондук-Даши предлогом стала предполагаемая перспектива расследования в Коллегии: «того ради оные Таракановы писма я у себя без утраты хранить должен». ДондукДаши поставил условие, что отдаст письма только после того, как увидит указ из Коллегии: «Без указу ж оных писем к вам я не послал. Егда ж! оные письма потребны будут, то неумедля ис коллегіи и указ пришлетца, а бес указу отдать вам я опасен, и сами можете разсудить, что, кроме того, в тех писмах никакой нужды не имеем. И в неприсылке оных меня предосудить не изволте». И, наконец, он использует такую лексику, которая указывала бы на его эмоциональное состояние: «нахожусь небесприскорбности и уповаю, что в том напрасно оклеветан», поскольку бригадир в препровождении персидского посла «злаго умысла уведал».

«Маленький эпизод» с утечкой информации от А. Тараканова на самом деле стоил В.Н. Татищеву и Коллегии иностранных дел многих усилий. В.Н. Татищеву было дано два задания. Первое - не допустить ухода калмыков за границу. Второе - тайно разведать о том, не было ли контактов с посланниками Надир-шаха у самого наместника ханства Дондук-Даши. Как известно, с первым заданием он вполне справился: вел тяжелые переговоры, развернул целую агентурную сеть. «С целью недопущения ухода калмыков за границу по указанию Татищева улусы Джан были переведены за Царицынскую укрепленную линию» [21, с. 55]. Но второе задание «благодаря Тараканову» В.Н. Татищев не смог осуществить. В этот период правительство не имело ничего, чтобы предъявить Дондук-Даши.

К счастью, данный инцидент, кроме нервов, дополнительных усилий, не имел последствий. Но, как показали дальнейшие события, наместник Калмыцкого ханства сам вступил в тайную переписку с правителем Персии в 1745 г. и по донесениям полковника Никиты Спицына имел намерение перейти на сторону Персии. И возможно, только смерть Надиршаха в 1747 г. положила конец надеждам наместника ханства сменить российское поддан- 
ство на персидское [21, с. 56]. Впрочем, как отмечает А. Цюрюмов: «в историографии практически не изучены внешнеполитические действия Дондук-Даши» [24, с. 267].

Другим проявлением протеста путем уклонения служит «неведение» калмыцкого наместника относительно позиции российского правительства о вооружении калмыков против казахов. Так, в 1742 г. на заседании Коллегии иностранных дел было рассмотрено донесение В.Н. Татищева о требовании Дондук-Даши «для охранения себя от внезапного нападения киргиз-кайсаков пушек». По этому поводу В.Н. Татищеву был отправлен указ от имени Елизаветы Петровны от 31 мая 1742 г., которым запрещалось посылать калмыкам «полковые пушки с артиллерийскими служителями из Астрахани, Царицына». При этом «из мелких пушек», которые давали до этого Дондук-Омбе, разрешалось оставить при новом наместнике только четыре пушки, а остальные было приказано «без указа, под приличным предлогом отобрать в российский город» [22]. Но, как следует из писем Дондук-Даши, в 1743 г. он как бы находился в неведении о планах правительства относительно вооружения калмыков, их позиции относительно калмыцко-казахских отношений. Дело в том, что в 1740-х гг. правительство было заинтересовано в сохранении мира между ними, поэтому не поощряло калмыков вести с казахами борьбу. Так, в письме от 13 января 1743 г. Дондук-Даши просил: «Которые обесчали пушки исправить об оных слышу, что ...имеются при бодокчи Даши Черене, о которых прошу наискорее починить прикажите». И в письме от 3 февраля 1743 г. ДондукДаши вновь возвращается к этой теме: «Донерпением кайсацких и персицких ведомостей заблаговременно против примеру прошлого года пороху и свинцу выдать прикажите ибо при случае за крайним временем взять будет невозможно, и при том прошу, которые обесчали пушки исправить оные по исправлении ко мне пришлите немедленно» [10, л. 23-23 об.]. На самом деле дело было не в пушках, а в скрытой просьбе калмыцкого наместника не запрещать калмыкам барымту на казахов.

И, наконец, есть в письмах Дондук-Даши Татищеву многочисленные свидетельства о том, что взаимоотношения между народами в Волго-Каспийском фронтире зачастую выходили за рамки, предписанных правительством. Так, в письме от 6 января 1743 г. Дондук-Даши советовался с В.Н. Татищевым по поводу того, что ответить нойону Бамбару на его вопрос по поводу требования Абулхаирхана выполнить договоренность, принятую еще во времена их родителей, о женитьбе младшего брата Бамбара (Ёмчина) на дочери Абулхаира [12, л. 28]. Информативная значимость данного письма в том, что наше понимание казахско-калмыцких отношений выходит за рамки барымты и взаимных набегов, в крайнем случае, торговых пересылок. Сегодня известен факт о стремлении казахских чингизидов жениться или сделать наложницей калмычек, чтобы иметь от них детей. К этому, кстати, стремились и некоторые владельцы горских народов Кавказа. Так, ханша Джан, жена хана Дондук-Омбы, была дочерью влиятельного кабардинского князя.

В своей книге А. Цюрюмов пишет о том, что казахский посланец на Волгу известил В.Н. Татищева о том, что дочь Дондук-Омбо была засватана за сына хана Среднего жуза Абулмамбета. Данный факт А. Цюрюмов приводит на основе источника «Журнал встреч В.Н. Татищева за 1741 г.» [24, с. 274]. Также письма Дондук-Даши содержат сведения о факте переписки с ханом Средней Орды Абулмамет-ханом. Так, 12 января 1743 г. Абулмамбет поздравляет Дондук-Даши с тем, что «государь вам поручил отцовское ханское место чему зело радуюся и желаю о[т]бога вам долгодейственного и благополучного пребывания». Казахский хан предлагал договориться о мирных отношениях, дружбе, всячески сдерживать подвластное население от набегов. Мы узнаем, что вместе с письмом Абулмамбет отправил посланцов: «причем моем писме о[т]правлены посланцы Ко[л]чук бек, А[л][ча батыр, Жакдар и когда оные до вас прибудет прошу неумедля с ответом во[3]вратить» [10, л. 12-12 об.]. Это очень важная информация, поскольку наши знания о калмыцкоказахских отношениях в этот период ограничивались только сношениями с ханами Младшего жуза. Намерение хана Среднего жуза заключить мир с волжскими калмыками и даже отправка посланников, имена которых 
приведены в письме, являются новым фактом, который требует дальнейшего изучения.

Результаты. Таким образом, на основе писем Дондук-Даши из Национального архива Республики Калмыкия был рассмотрен взгляд наместника Калмыцкого ханства на некоторые мероприятия В.Н. Татищева, когда он возглавлял Калмыцкую комиссию. В основу статьи была положена аналитическая категория «протест путем уклонения». Анализ писем, исходящих от Дондук-Даши, показывает, что он очень хорошо владел как внутриполитической, так и внешнеполитической ситуацией Калмыцкого ханства 1741-1745 годов. Как ставленник российского правительства Дондук-Даши был вполне вписан в российскую систему, иерархию власти на местах. Об этом говорит «употребление метафорических терминов родства “старший брат”, “младший брат”» [16]. В то же время, исходя из писем, нельзя говорить о его безоговорочном подчинении. Об этом свидетельствуют три примера, приведенные в данной статье. Каждый пример представляет собой, на первый взгляд, безобидные и ничего не значащие факты. Но когда мы включаем в анализ исторический контекст, получается, что каждый мелкий инцидент имел своим последствием затруднение, препятствие на пути интеграции региона в состав Российской империи. Такой взгляд со стороны подвластных народов позволяет нам увидеть, говоря словами П. Верта, «как эта власть зачастую должна была тратить значительные усилия (пусть даже временно), чтобы снова скрепить распадающееся единство и закамуфлировать наметившиеся линии раскола» [2, с. 57]. Но для такой перспективы изучения нужны источники, исходившие непосредственно от подвластных народов. В этом смысле трудно переоценить возможности, которые нам открывает Национальный архив Республики Калмыкия, где содержится богатейший материал по русско-казахским и русско-калмыцким взаимоотношениям в XVIII веке. В частности, там хранятся более сорока дел в папках, каждая из которых содержит от двухсот до тысячи шестисот листов документов Калмыцкой комиссии 17411745 гг., когда ее главой был В.Н. Татищев. И среди них много документов, писем, исходящих непосредственно от калмыцких и казахских владетелей.

\section{ПРИМЕЧАНИЕ}

\begin{abstract}
${ }^{1}$ Работа выполнена в рамках стратегического проекта «Калмыкия как трансграничный регион в восточном векторе России». Данный проект был реализован в рамках программы развития Калмыцкого государственного университета им. Б.Б. Городовикова как опорного регионального университета и поддержан внутривузовским грантом 2019 г. № 1094 «Русско-калмыцко-казахские отношения» (на материале документов Калмыцкой комиссии, хранящихся в Национальном архиве Республики Калмыкия, в бытность его главой В.Н. Татищева)».

The paper was carried out as part of the strategic project "Kalmykia as a transboundary region in the eastern vector of Russia". This project was implemented within the development program of the B.B. Gorodovikov Kalmyk State University as a pivotal regional university. It was supported by the intrauniversity grant of 2019 No. 1094 "Russian-KalmykKazakh relations" (based on the documents of Kalmyk Commission headed by V.N. Tatishchev stored in the Republic of Kalmykia National Archives.
\end{abstract}

\section{СПИСОК ЛИТЕРАТУРЫ}

1. Батмаев, M. М. Калмыки в XVII-XVIII веках. События, люди, быт / М. М. Батмаев. - Элиста : Калмыц. кн. изд-во, 1993. - 381 с.

2. Верт, П. От сопротивления к подрывной деятельности: власть империи, противостояние местного населения и взаимозависимость / П. Верт // Российская империя в зарубежной историографии. Работы последних лет: Антология. - М. : Новое издательство, 2005. - С. 18-48.

3. Выписка о склонении персидским шахом калмыков под его покровительство // Архив внешней политики Российской империи (далее - АВПРИ). 1742. -Ф. 119.-Оп. 119/1. - Д. 39.

4. Кундакбаева, Ж. Б. В.Н. Татищев - «строитель империи» на юго-восточных окраинах России / Ж. Б. Кундакбаева // В.Н. Татищев и проблемы государственно-административного управления в России : материалы Междунар. науч. конф., 5-7 окт. 2006 г. / сост.: В. В. Ишин, И. В. Торопицын. - Астрахань : Издательский дом «Астраханский университет», 2006. - С. 291-295.

5. Кундакбаева, Ж. Б. «Знаком милости Е.И.В.» Россия и народы Северного Прикаспия в XVIII веке / Ж. Б. Кундакбаева. - М. : АИРО-ХХІ ; СПб. : Дмитрий Буланин, 2005. - 303 с. - Серия «АИРО-монография».

6. Пальмов, Н. Н. К астраханскому периоду жизни В.Н. Татищева / Н. Н. Пальмов // Известия Российской академии наук. VI серия. - 1925. - Т. 19, вып. 6-8 . - С. 201-216. 
7. Пальмов, Н. Н. К астраханскому периоду жизни В.Н. Татищева / Н. Н. Пальмов // Известия академии наук СССР. Сер. 7. - 1928. - № 4-7. - С. 317-342.

8. Пальмов, Н. Н. Этюды по истории приволжских калмыков. Ч. II. XVIII век / Н. Н. Пальмов. Астрахань : Калмоблиздат, 1927. - 266 с.

9. Письмо Дондук-Даши В.Н. Татищеву от 3 января 1743 г., перевод XVIII в. // Бюджетное учреждение Республики Калмыкия «Национальный Архив» (БУРКНА). - Ф. 36. - Оп. 1. - Д. 163.

10. Письмо Дондук-Даши Татищеву от 3 января 1743 г. // БУРКНА. - Ф. 36. - Оп. 1. - Д. 163.

11. Попов, Н. В.Н. Татищев и его время / Н. Попов. - М. : В типографии В. Грачева и К, 1861. -803 с.

12. Путевые дневники и записки российских чиновников и исследователей о Казахской степи XVIII - середины XIX века : сб. док. и материалов / сост. И. В. Ерофеева, Б. Т. Ханаев, И. М. Самигулин. - Астана : ТОО «Общество инвалидов - Чернобылец», 2012. - 758 с.

13. Рапорт Тараканова в Высочайший Его Императорского Величества Кабинет от 13 октября 1741 г. // АВПРИ. - 1741.-Ф. 119. -Оп. 119/1.-Д. 19.

14. Рапорт Тараканова в Высочайший Его Императорского Величества Кабинет от 25 ноября 1741 г. // АВПРИ.-1741.-Ф. 119. -Оп. 119/1. -Д. 19.

15. Рапорт Тараканова в Высочайший Его Императорского Величества Кабинет от 20 декабря 1741 г. // АВПРИ. - 1741. -Ф. 119. -Оп. 119/1. -Д. 19.

16. Сусеева, Д. А. «Для построения оной крепостцы заугодные места усмотрены меж Астрахани и Черного Яра». В.Н. Татищев и Енотаевская крепость в русско-калмыцких отношениях. 17421745 гг. / Д. А. Сусеева // Исторический архив. - М., 2016. - № 4. - С. 185-190.

17. Сусеева, Д. А. Письма калмыцких ханов XVIII века и их современников (1713-1771 гг.). Избранное / Д. А. Сусеева. - Элиста : ЗАОР НПП «Джангар», 2009. - 992 с.

18. Торопицын, И. В. В.Н. Татищев: «...В Черном Яру, Енотаевской и Кизлярской крепостях... иметь крепкую предосторожность». Строительство и реконструкция укреплений в Нижнем Поволжье и на Северном Кавказе в 1740-х годах / И. В. Торопицын // Военно-исторический журнал. - 2013. Вып. 3. - С. 48-52.

19. Торопицын, И. В. Оборона калмыцких улусов в 30-40-х гг. XVIII в. / И. В. Торопицын // Единая Калмыкия в единой России: через века в будущее : материалы Междунар. науч. конф., посвящ. 400-летию добровольного вхождения калмыцкого народа в состав Российского государства (г. Элиста, 1318 сентября 2009 г.) : в 2 ч. Ч. 1. - Элиста : 3 АОр «НПП «Джангар», 2009. - С. 242-246.

20. Торопицын, И. В. Переселение крещеных калмыков в Ставрополь на Волге / И. В. Торопицын
// Архив Русской истории. - М. : Древлехранилище, 2002. - № 7. - С. 107-124.

21. Торопицын, И. В. Противодействие тайного советника и губернатора В.Н. Татищева планам ханши Джан разыграть персидскую карту в русско-калмыцких отношениях в середине XVIII века / И. В. Торопицын // Вестник Калмыцкого института гуманитарных исследований РАН. - 2010. - № 1. C. 52-56.

22. Указы Татищеву по делам киргиз-кайсацким // АВПРИ. - 1742. - Ф. 122. - Оп. 122/1. - Д. 3.

23. Хараева, А. Т. Русские заимствованные слова в калмыцком языке XVIII века (на материале официально-деловых писем калмыцких ханов XVIII века и их современников) : дис. ... канд. филол. наук / Хараева Анна Тимуровна. - Элиста, 2013. -243 c.

24. Цюрюмов, А. В. Калмыцкое ханство в составе России: проблемы политических взаимоотношений / А. В. Цюрюмов. - Элиста : ЗАОр «НПП «Джангар», 2007. - 464 с.

\section{REFERENCES}

1. Batmaev M.M. Kalmyki v XVIIXVIII vekakh. Sobytiya, lyudi, byt [Kalmyks in the $17^{\text {th }}-18^{\text {th }}$ c. Events. People. Life]. Elista, Kalmytskoe knizhnoe izd-vo, 1993. 381 p.

2. Vert P. Ot soprotivleniya $\mathrm{k}$ podryvnoy deyatelnosti: vlast imperii, protivostoyanie mestnogo naseleniya i vzaimozavisimost [From Resistance to Subversion: The Power of the Empire, the Opposition of the Local Population and Interdependence]. Rossiyskaya imperiya v zarubezhnoy istoriografii. Raboty poslednikh let: Antologiya [The Russian Empire in Foreign Historiography. Works of Recent Years: Anthology]. Moscow, Novoe izdatelstvo, 2005, pp. 18-48.

3. Vypiska o sklonenii persidskim shakhom kalmykov pod ego pokrovitelstvo [Extract of the Persian Shah Declination of Kalmyks Under His Patronage]. Arkhiv vneshney politiki Rossiyskoy imperii (dalee - AVPRI) [Archive of Foreign Policy of the Russian Empire], 1742, f. 119, inv. 119/1, d. 39.

4. Kundakbayeva Zh.B. V.N. Tatishchev «stroitel imperii» na yugo-vostochnykh okrainakh Rossii [V.N. Tatishchev as a Builder of the Empire on the South-Estern Borderlines of Russia]. IshinV.V., Toropitsyn I.V., eds. V.N. Tatishchev i problemy gosudarstvenno-administrativnogo upravleniya $v$ Rossii: materialy Mezhdunar. nauch. konf., 5-7 okt. 2006 g. [V.N. Tatishchev and Problems of StateAdministrative Management in Russia: Proceeings of the International Scientific Conference, October 5-7, 2006]. Astrakhan, Izdatelskiy dom «Astrakhanskiy universitet», 2006, pp. 291-295. 
5. Kundakbayeva Zh.B. «Znakom milosti E.I.V.» Rossiya i narody Severnogo Prikaspiya v XVIII veke [As a Mark of the His Imperial Majestys Favor. Russia and Northern Caspian Peoples in the $18^{\text {th }}$ c.]. Moscow, AIRO-XXI Publ.; Saint Petersburg, Dmitriy Bulanin Publ., 2005. 303 p. (Seriya «AIRO-monografiya» [“AIRO-monografiya” Series]).

6. Palmov N.N. K astrakhanskomu periodu zhizni V.N. Tatishcheva [The Astrakhans Period of V.N. Tatishchevs Life]. Izvestiya Rossiyskoy akademii nauk. VI seriya, 1925, vol. 19, iss. 6-8, pp. 201-216.

7. Palmov N.N. K astrakhanskomu periodu zhizni V.N. Tatishcheva [The Astrakhans Period of V.N. Tatishchevs Life]. Izvestiya akademii nauk SSSR, Ser. 7, 1928, no. 4-7, pp. 317-342.

8. Palmov N.N. Etyudy po istorii privolzhskikh kalmykov. Ch. II. XVIII vek [Sketches on the History of the Wolga Kalmyks. Part 2. $18^{\text {th }}$ c.]. Astrakhan, Kalmoblizdat, 1927.266 p.

9. Pismo Donduk-Dashi V.N. Tatishchevu ot 3 yanvarya 1743 g., perevod XVIII v. [The Letter from Donduk-Dashi to V.N. Tatishchev of January 3d, 1743]. Byudzhetnoe uchrezhdenie Respubliki Kalmykiya «Natsionalnyy Arkhiv» (BURKNA) [National Archive of the Republic of Kalmykia], f. 36, inv. 1, d. 163.

10. Pismo Donduk-Dashi Tatishchevu ot 3 yanvarya $1743 \mathrm{~g}$. [The Letter from Donduk-Dashi to V.N. Tatishchev of January 3, 1743. Translation of the $18^{\text {th }}$ c.]. Byudzhetnoe uchrezhdenie Respubliki Kalmykiya "Natsionalnyy Arkhiv» (BURKNA) [National Archive of the Republic of Kalmykia], f. 36, inv. $1, \mathrm{~d} .163$.

11. Popov N. V.N. Tatishchev i ego vremya [V.N. Tatishchev and His Period]. Moscow, V tipografii V. Gracheva i K, 1861. 803 p.

12. Erofeeva I.V., Khanaev B.T., Samigulin I.M. Putevye dnevniki i zapiski rossiyskikh chinovnikov $i$ issledovateley o Kazakhskoy stepi XVIII - serediny XIX veka: sb. dok. i materialov [Travel Diaries and Notes of Russian Officials and Researchers on the Kazakh Steppe $18^{\text {th }}-$ Mid- $19^{\text {th }}$ Century. Collection of Documents and Materials]. Astana, TOO «Obshchestvo invalidov-Chernobylets», 2012. 758 p.

13. Raport Tarakanova v Vysochayshiy Ego Imperatorskogo Velichestva Kabinet ot 13 oktyabrya 1741 g. [Tarakanovs Report to the His Imperial Majestry Office of October 13, 1741]. AVPRI [Archive of Foreign Policyof the Russian Empire], 1741, F. 119, Op. 119/1, D. 19.

14. Raport Tarakanova $\mathrm{v}$ Vysochayshiy Ego Imperatorskogo Velichestva Kabinet ot 25 noyabrya $1741 \mathrm{~g}$. [Tarakanovs Report to the His Imperial Majestry Office of November 25, 1741]. AVPRI [Archive of Foreign Policy of the Russian Empire], 1741, f. 119, inv. 119/1, d. 19.

15. Raport Tarakanova v Vysochayshiy Ego Imperatorskogo Velichestva Kabinet ot 20 dekabrya
1741 g. [Tarakanovs Report to the His Imperial Majestry Office of December 20, 1741]. AVPRI [Archive of Foreign Policy of the Russian Empire], 1741, f. 119, inv. 119/1, d. 19.

16. Suseeva D.A. «Dlya postroeniya onoy kreposttsy zaugodnye mesta usmotreny mezh Astrakhani i Chernogo Yara». V.N. Tatishchev i Enotaevskaya krepost $\mathrm{v}$ russko-kalmytskikh otnosheniyakh. 1742-1745 gg. [In Search of Place for the Fortess We Find the Space Between Astrahan and Chernyy Yar. V.N. Tatishchev and Enotaevskii Fortress in Relations Between Russians and the Kalmyks, 17421745]. Istoricheskiy arhiv [Historical Archive], Moscow, 2016, no. 4, pp. 185-190.

17. Suseeva D.A. Pisma kalmytskikh khanov XVIII veka $i$ ikh sovremennikov (1713-1771 gg.). Izbrannoe [Letters of the Kalmyk Khans of the $18^{\text {th }}$ Century and Their Contemporaries (1713-1771). Selected Works]. Elista, ZAOR NPP «Dzhangar», 2009. $992 \mathrm{p}$.

18. Toropitsyn I.V. V.N. Tatishchev: «...VChernom Yaru. Enotaevskoy i Kizlyarskoy krepostyakh... imet krepkuyu predostorozhnost». Stroitelstvo i rekonstruktsiya ukrepleniy v Nizhnem Povolzhye i na Severnom Kavkaze v 1740-kh godakh [V.N. Tatishchev: "To Take All Precautions... In Chernyy Yar, Enotaevsk and Kizlyar Fortesses". Construction and Reconstruction of Fortifications in the Lower Volga Region and the North Caucasus in the 1740s]. Voennoistoricheskiy zhurnal [Military and Historical Journal], 2013, iss. 3, pp. 48-52.

19. Toropitsyn I.V. Oborona kalmytskikh ulusov v 30-40-kh gg. XVIII v. [The Defense of the Kalmyk Uluses in the $30 \mathrm{~s}-40 \mathrm{~s}$ of the $18^{\text {th }}$ Century]. Edinaya Kalmykiya $v$ edinoy Rossii: cherez veka $v$ budushchee: materialy Mezhdunar. nauch. konf., posvyashch. 400-letiyu dobrovolnogo vkhozhdeniya kalmytskogo naroda $v$ sostav Rossiyskogo gosudarstva (g. Elista, 13-18 sentyabrya 2009 g.): v 2 ch. Ch. 1 [United Kalmykia in United Russia: Through the Centuries To the Future: Proceedings of the International Scientific Conference to the $400^{\text {th }}$ Anniversary of the Voluntary Entering of Kalmyk People into the Russian State (Elista, September 1318, 2009). In 2 Parts. Part 1]. Elista, ZAOr «NPP «Dzhangar», 2009, pp. 242-246.

20. Toropitsyn I.V. Pereselenie kreshchenykh kalmykov v Stavropol na Volge [Relocation of Christened Kalmyks to the Stavropol on the Volga]. Arkhiv Russkoy istorii [The Russian History Archive]. Moscow, Drevlekhranilishche Publ., 2002. no. 7, pp. 107-124.

21. Toropitsyn I.V. Protivodeystvie taynogo sovetnika i gubernatora V.N. Tatishcheva planam khanshi Dzhan razygrat persidskuyu kartu v russkokalmytskikh otnosheniyakh v seredine XVIII veka 
[Counteraction of the Privy Counselor and Governor V.N. Tatishchev to the Plans of Khanshi Jan to Play the Persian Card in the Russian-Kalmyk Relations in the Middle of the XVIII Century]. Vestnik Kalmytskogo instituta gumanitarnykh issledovaniy RAN, 2010, no. 1, pp. 52-56.

22. Ukazy Tatishchevu po delam kirgiz-kaysatskim [Decrees to Tatishchev on Kyrgyz-Kaysak Affairs]. AVPRI [Archive of Foreign Policy of the Russian Empire], 1742, f. 122, inv. 122/1, d. 3.

23. Kharaeva A.T. Russkie zaimstvovannye slova $v$ kalmytskom yazyke XVIII veka (na materiale ofitsialno-delovykh pisem kalmytskikh khanov XVIII veka i ikh sovremennikov): dis. ... kand. filol. nauk [Russian Borrowed Words in the Kalmyk Language of the $18^{\text {th }}$ Century (On the Material of the Official and Business Letters of the Kalmyk Khans and Their Contemporaries of the $18^{\text {th }}$ Century)]. Elista, 2013. 243 p.

24. Tsyuryumov A.V. Kalmytskoe khanstvo $v$ sostave Rossii: problemy politicheskikh vzaimootnosheniy [The Kalmyk Khanate in the Composition of Russia: Problems of Political Relations]. Elista, ZAOr «NPP «Dzhangar», 2007. 464 p.

\section{Information About the Authors}

Zhanat B. Kundakbayeva, Doctor of Sciences (History), Professor, Al-Farabi Kazakh National University, Prosp. Al-Farabi, 71, 050040 Almaty, Republic of Kazakhstan, janbekkun@mail.ru, https://orcid.org/0000-0003-3074-6332

Danara A. Suseeva, Doctor of Sciences (Philology), Professor, B.B. Gorodovikov Kalmyk State University, Pushkina St, 11, 358000 Elista, Republic of Kalmykia, Russian Federation, suseeva@gmail.com, https://orcid.org/0000-0001-8814-8007

\section{Информация об авторах}

Жанат Бековна Кундакбаева, доктор исторических наук (РФ и РК), профессор, Казахский национальный университет им. аль-Фараби, просп. аль-Фараби, 71, 050040 г. Алматы, Республика Казахстан, janbekkun@mail.ru, https://orcid.org/0000-0003-3074-6332

Данара Аксеновна Сусеева, доктор филологических наук, профессор, Калмыцкий государственный университет им. Б.Б. Городовикова, ул. Пушкина, 11, 358000 г. Элиста, Республика Калмыкия, Российская Федерация, suseeva@gmail.com, https://orcid.org/0000-0001-8814-8007 